
THE FISHERIES OF JAPAN CONSIDERED FROM A GEOGRAPHICAL STANDPOINT

\author{
* \\ By T. Kitahara, Ph. D. \\ Imperial Fisheries Bureau of Japan \\ *
}

Paper presented before the Fourth International Fishery Congress

held at Washington, U. S. A., September 22 to 26, 1908

BULLETIN OF THE BUREAU OF FISHERIES $: \quad: \quad: \quad: \quad:$ VOL. XX́VIII, P. 375-379

Document No. 665 : : : : : : : : : : : : : : : : : Issued February, 1910 
MAR ¿ 1910

D. 당

$$
\because \vdots
$$




\title{
THE FISHERIES OF JAPAN CONSIDERED FROM A GEOGRAPHICAL STANDPOINT.
}

\author{
$*$ \\ By T. KITAHARA, Ph. D., \\ Imperial Fisheries Bureau of Japan.
}

It is a well-known fact that the Japanese are among the most extensively fish-eating people of the world. The average annual consumption of fish in Japan, to my estimation, is nearly 50 pounds per head, a high average not surpassed by other nations, except the Norwegians and the Canadians. Although the preference for fish as an article of food is said to have originated from some religious belief in the old time, now the people of Japan are in the position of being forced to take it as the most important diet, because they have very small pasture for raising cattle, while there are seas to fish near at hand all around the country.

The Empire of Japan, as you know, stands off the northeast coast of Asia, stretching from southwest to northeast for nearly 3,000 miles, and from the tropical to nearly the frigid zone, washed by the warm as well as the cold currents. Thus it can be seen that Japan, so far as the maritime conditions are concerned, is much like the Eastern States of North America. The Gulf Stream may be compared with the Japan Current, the Labrador Current with the' Kurile Current, the Gulf of St. Lawrence, probably, with the Japan Sea. The fishes which inhabit the waters of Japan are also like those of America to some extent, as regards both character and distribution.

But unfortunately we lack such great fishing banks as the Grand Banks off Newfoundland, the Georges Bank off Cape Cod, etc. On the contrary, Japan has the deep abysses along the east coast which are useless for the fishing industry, but give rise to the terrible earthquakes and awful tidal waves that at times destroy lives and property along the shore. This condition seriously affects the development of the fisheries in that part of the country. In fact, the Japanese islands, being as a whole steeply built, have but few submarine plateaus. The area within the roo-fathom line, i. e., the continental shelf, is only about 77,000 square miles, while that of the Chinese and the Korean seas comprises nearly 200,000 square miles, and that of North America about I,OOo,00o square miles. 
It naturally follows, therefore, that the fishermen cling to the shore for the bank fishing, and consequently their boats are very small and not ocean-rigged, being mostly shorter than 30 feet. Such small boats now number 400,000 , and they are very densely distributed on the comparatively narrow shore fishing grounds, which are so actively fished over that the important shore fishes have been greatly decreased. I believe the shore fisheries of Japan are in the climax of development, and there seems to be very little room for further increase. The only hope for future progress rests upon the growth of the pelagic fisheries on the deep high seas.

Understanding these conditions in regard to the fisheries of Japan, we come to consider:

I. How to repopulate the depleted shore fishing grounds.

2. How to encourage the pelagic fisheries in general.

The first question is very difficult to solve, and when solved is not easy to practice, and we can not as yet report any good results, except in the artificial propagation of the salmon, on which I shall touch later. As to the second question, to make effective encouragement an act was passed by the Imperial Diet in 1897 by which fishing steamers of more than 50 tons and sailing vessels of more than 30 tons may receive certain subsidies from the Government. Since this act has been in force several vessels have equipped for the pelagic fisheries, but unfortunately the greater number of these vessels were for pelagic sealing, which is regarded with such disfavor by the American and Russian authorities. In my country, too, the increase of sealing vessels is not encouraged. Indeed, the profit from the fur seals is very limited, and it is not a wise policy to promote an industry which causes so much international difficulty.

The amendment to the act and the by-laws in 1905 were with the view that all important pelagic fisheries may receive subsidies. The lower limit of tonnage of sailing vessels was therefore reduced to 20 tons. Moreover, in case of vessels newly built under the instructed plan, they also may have a certain support from the Government. These amendments proved effective, and many fishing vessels were equipped for pelagic fisheries other than sealing. Among other vessels the Fuji Maru, of 25 tons, with an auxiliary gasoline motor, made a great catch in bonito fishing in 1906, which resounded throughout all the fishing communities, awakening the fishermen from a long sleep in the old methods of fishing. I believe Japan will have a great revolution in her fishing vessels within a few years, and will as a consequence increase the supply of the pelagic food fish.

It is a significant fact that the whale fishery on the high seas has sprung up with fullest vigor since r905, almost regardless of the government encouragement. There are now 28 whaling steamers, while there were only 2 schooners in I904. This wonderful development of whaling is, I think, partly because of the prohibition of whaling in the Norwegian seas and partly because of the 
abundance of whales in the seas of Japan. Most of the gunners employed are from Norway.

Before closing I want to call your attention to some of the methods of fishing and fish culture introduced from America. The most important of these is the purse seine. It was first introduced into Japan by Mr. K. Sekigawa thirty years ago. After a good deal of encouragement, it was applied to the catching of sardines and herring; and now hundreds of such seines are being used on the southeast coast. It is not yet used for mackerel fishing, as in America. The artificial propagation of salmon and trout, which was introduced by the same man, is no less interesting; and Japan owes much to the kindness of the American authorities. There are now some 20 hatcheries in northern Japan, which annually yield about 35,000,000 fry. The fishermen are now in firm conviction that the beneficial results of artificial propagation of the salmon are beyond doubt. In fact, they have established by themselves several hatcheries at their fishing grounds. The rainbow trout, which was first introduced thirty years ago and new lots of which have been brought over several times since then, is thriving well in the lakes at Nikko and Aizu.

I have great pleasure in expressing thanks in behalf of my country for the ever kind aid that the American authorities have given for the promotion of Japanese fisheries and fish culture. 



\section{LIBRARY OF CONGRESS}

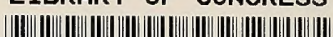

